\title{
Inhabitation of Larger Mammals in the Alai Valley of the Kyrgyz Republic
}

\section{キルギス共和国，アライ谷の大型哺乳類の生息状況}

\author{
Shigeyuki IZUMIYAMA* , Maksat ANARBAEV** and Teiji WATANABE*** \\ 泉山 茂之*・マクサト アナルバエフ**・渡辺 悌二***
}

Key words : larger mammals, distribution, Alai Valley, The Kyrgyz Republic

キーワード：大型哺乳動物, 分布, アライ谷, キルギス共和国

\begin{abstract}
要旨
キルギス共和国南部のアライ谷地域で，地元ハンターへの聞き取りと住民へのアンケート調査を中心に，現存する大型 野生動物のリストを作成し，この地域にみられる問題点を明らかにした。その結果，13種の動物をリストアップした。こ の中には, ソ連邦崩壊後に増加したオオカミと, 絶滅の危機に瀕しているマルコポーロ・シープ, 現在も続く狩猟によっ て個体数が激減していると考えられるアイベックスが含まれている。オオカミの群れはいわゆる「里オオカミ」として集 落付近で定着するようになっている。これは, ソ連邦時代には国家がオオカミを害獣として組織的に捕殺していたのに, 現在では地域の住民が自ら対応しなければならなくなった結果である。オオカミの駆除は必ずしも好ましいとは言えな いが, 少なくとも人間の居住地域からの排除は必要である。また, マルコポーロ・シープについては, タジキスタン国 境に近い，住民の立ち入りが困難なザ・アライ山脈のある地域を除いてすでに絶滅が進行してしまっている。アイべッ クスについては, 新型の銃器による違法狩猟が続いており, 食肉用に捕獲されるため, 狩猟された個体がトラックの荷台 に満載されていたという目撃情報も複数存在している。こうした現状から, 実効性のある対策が急務であるが, この地域 の生物資源保全を有効に進める一つの貢献として, 現在, 議論が進んでいる, パミール・アライ国際自然保護地域の設立 (PATCAプロジェクト) が期待される。しかしながらアンケート調査によれば, このプロジェクトの計画の存在を知っ ていた住民はわずか $16.9 \%$ (331人中 56 人)に過ぎなかった。
\end{abstract}

\section{I . Introduction}

The Kyrgyz Republic is a mountainous country in which lie several mountain ranges, from the northern Pamirs to the Tian Shan Mountains. The land is characterized by a distinctive landscape and abundant natural resources including various rare animals such as argali (Ovis ammon) and snow leopards (Panthera uncia). The government, however, approves the trophy hunting of some animal species, and in addition, illegal hunting aggravates the resource condition. In particular, target animals such as argali and ibex (Capra ibex) are quickly reducing in number (Watanabe et al., 2008) .

Therefore, in order to attain well-organized management of wildlife, it is essential to be aware of the actual condition. However, no survey, intended towards better management, has ever been conducted in the past; it is one of the challenges for the country. In this context, the present study, although based on a short-term survey, aims to understand the wildlife conditions in the Alai (Alay) Valley. Despite the short-term survey, this study may contribute in revealing the current wildlife

\footnotetext{
* Faculty of Agriculture, Shinshu University, Japan / 信州大学農学部

**National Center for Mountain Regions Development, The Kyrgyz Republic／キルギス国立山岳地域開発研究センター ***Faculty of Environmental Earth Science, Hokkaido University, Japan/北海道大学地球環境科学研究院
} 
conditions of this area.

\section{II . Study area}

The Alai Valley (Fig. 1) is located in the southern Osh Oblast (Province), a region in the northern Pamirs. The valley is formed in the headwater areas of the Amuderya (Amu Darya, Amu Dar'ya) River where the elevation of the river basin is measured at 2,600-3,000 m. The basin stretches from east to west between two mountain ridges. The Kyzyl Suu (suu means 'river') flows on the valley floor towards the west, crossing the national border into the Republic of Tajikistan (hereafter, referred to as Tajikistan). To the north of the valley, lie the ridges of the Alai Range, nearly 5,000 m high, from east to west. To the south, at the national border between Kyrgyz

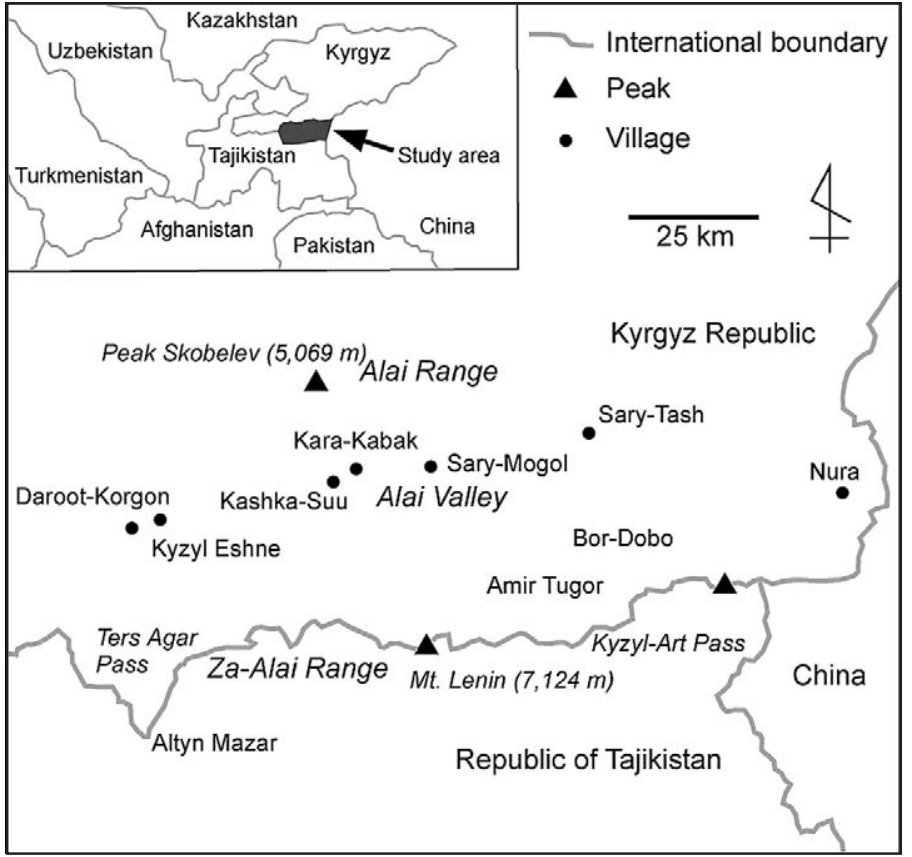

Fig. 1 Study area. and Tajikistan, lies the $\mathrm{Za}$-Alai $\left(\mathrm{Za}^{-}\right.$ alay) Range of over 6,000 $\mathrm{m}$ a.s.l. aligns, of which the highest peak is Mt. Lenin $(7,124 \mathrm{~m})$. There exist two passes in the Za-Alai Range which mark the border between Kyrgyzstan and Tajikistanthe Kyzyl-Art Pass $(4,336 \mathrm{~m})$ and the Ters Agar Pass $(3,598 \mathrm{~m})$. The road through the KyzylArt Pass plays a vital role in daily-life transportation for the residents in the Tajik Pamirs. The Ters Agar Pass has a jeep road to Altyn Mazar $(2,900 \mathrm{~m}$ ) on the Tajik side where a shrine (mazar) and a graveyard exist.

Human life depends mainly on livestock farming such as that of sheep, goat, cattle, yak, and horse. The cold climate enables only limited cultivation of potatoes, wheat, buckwheat, and pasture grass.

\section{Method}

The survey was performed from 7 November to 23 November 2008. The procedures undertaken were as follows:

1. Bibliographic survey: Referred to documents, as listed in the references in the end, including: Editorial Board of the Chinese Academy of Sciences (1979), Sekai Bunka Publishing (1985), MacDonald (1986), Kyrgyz SSR Academy of Sciences (1987), and Kyrgyz Republic (2002).

2. Interviews: We met and conducted interviews with the following six hunters:

11 November: Mr. Ormonov AIDAR in Kashka-Suu (born in 1958)

12 November: Mr. Mamajunusov SURAN in Daroot-Korgon (78 years old) 
13 November: Mr. Imash MURZAKANOV in Kara-Kabak (born in 1959)

13 November: Mr. Jooshbai JEENEKOV in Sary-Mogol (born in 1945)

14 November: Mr. Juma KOSHONOV in Sary-Mogol (50 years old)

21 November: Mr. Asanov ABJAPAR in Sary-Tash (born in 1959)

3. Inquiry using a questionnaire: We visited seven schools in the villages located in the Alai Valley and asked the teachers and children to hand over the questionnaire sheets to the parents. The sheets were later retrieved; the questionnaire sheet prepared in Kyrgyz was distributed to 514 households, out of which, 331 households responded.

4. Field survey: The survey was conducted by car, on a donkey, and on foot. We visually searched for animals as well as for their field signs.

$1^{\text {st }}$ survey (14 November) from Sary-Mogol village to Amir Tugor (3,330 m a.s.l.)

$2^{\text {nd }}$ survey (16 November) from Kara-Kabak village, following the ridges, to Peak Skobelev (5,069 m) up to $3,300 \mathrm{~m}$ a.s.l.

$3^{\text {rd }}$ survey (17 November) from Kyzyl Eshne village to a point in the northern valley at an elevation of $3,100 \mathrm{~m}$

IV. Results and Discussion

1. List of the major larger mammals

Information of the larger mammals obtained from the present study has been listed in Table 1 . The followings are some details for each animal species.

Table 1. List of larger mammals in the Alai Valley of the Kyrgyz Republic.

\begin{tabular}{|c|c|c|c|c|c|c|}
\hline Order & Species name & Nomenclature & Reference & Questionnaire & Hearing & Observation \\
\hline Lagomorpha & Mountain Hare & Lepus timidus & 0 & 0 & 0 & (Footprint) \\
\hline Rodentia & Long-tailed Marmot & Marmota caudata & 0 & 0 & 0 & \\
\hline \multirow[t]{8}{*}{ Carnivora } & Wolf & Canis lupus & 0 & 0 & 0 & (Footprint) \\
\hline & Red fox & Vulpes vulpes & 0 & 0 & ○ & (Observe) \\
\hline & Brown bear & Ursus arctos & 0 & 0 & ○ & \\
\hline & Weasel sp. & Martes sp. & 0 & ○ & ○ & \\
\hline & Stone Marten & Martes foina & 0 & 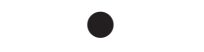 & 0 & (Footprint) \\
\hline & Badger & Meles meles & 0 & 0 & 0 & \\
\hline & Lynx & Lynx lynx & 0 & 0 & 0 & \\
\hline & Snow leopard & Panthera uncia & ○ & ○ & ○ & \\
\hline \multirow[t]{3}{*}{ Artiodactyla } & Wild boar & Sus scrofa & ○ & ○ & ○ & \\
\hline & Ibex & Capra ibex & ○ & 0 & 0 & (Footprint) \\
\hline & Argali & Ovis ammon & 0 & 0 & 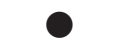 & \\
\hline
\end{tabular}

(1) Mountain Hare

This hare is considered to have a widely distributed population. We identified its footprints in the snow. 


\section{(2) Long-tailed Marmot}

The marmot is commonly found in the area. According to the photograph possessed by a villager, it is probably a long-tailed marmot (Marmota caudata). However, since the survey was conducted during the hibernation period, we were unable to confirm the presence of the animal in the field. Nevertheless, several reports of damage to farm crops have been made.

(3) Wolf

It is widely distributed throughout the area, from the vicinity of the villages to the back mountains. Damage to livestock is increasing year by year, and it is becoming a significant problem within the region. Attacks by wolves are also reported in the villages. Further, not only are sheep and goats the victims, but they also attack larger animals like the donkey and yak. However, it is rather difficult to determine whether it is the wolves that are responsible for all these attacks since they occur at night. Although the local authority encourages wolf-capturing with rewards, the hunting and killing of a wolf is a difficult task and damages are not alleviated. The low hunter population, owing to complicated procedures in acquiring licenses for gun possession may be another factor for the low removal rate. The packs of wolves that cause damage consist of several, almost twenty, individual animals. This number suggests that a socially-stable wolf population constantly inhabits the area around the villages.

(4) Red fox

This fox is widely distributed in the vicinity of the villages and in the back mountains. We visually identified individual foxes and observed many pawprints. Furthermore, many reports on damages to domestic chickens have been made.

(5) Brown bear

A small number of this species inhabits the back mountains. However, it is said that some bears are still seen in the Altyn mazar. A hunter described that 3 bears (a mother and cubs) were shot down on a slope near Mt. Lenin in 1964. Visually identified information in the same area was recorded in 1977, and no information has been obtained since then. Some other villagers account for the fact that no bears presently inhabit the area.

\section{(6) Weasel}

Although an interview revealed the inhabitance of the small-sized weasel, we were unable to determine whether it is the least weasel (Martes nivalis) or the ermine (Martes erminea).

(7) Stone marten

Frequently identified pawprints indicated that marten commonly inhabit the area. An old stuffed specimen seemed to be that of a stone marten (Martes foina), but we were unable to confirm it in the field.

(8) Badger

A large number of badgers inhabit the area.

(9) Lynx

It is assumed that some lynx are found in Tajikistan over the Kyzyl-Art Pass. Our interviews revealed that some lynx had inhabited the Alai Range in the past, but no confirming field information was obtained. A small number is also said to inhabit Altyn Mazar, an area near the national border between Kyrgyz and Tajikistan.

(10) Snow leopard

Snow leopards also previously inhabited the Alai Range, but continuous hunting for fur is said 
to have resulted in their extinction. One piece of fur costs as much as 70 million Rubles. Some are said to still remain in Altyn Mazar. Furthermore, there was information that, 20 years ago, leopards were seen around Nura near the national border between Kyrgyz and China, but we obtained no confirming information whether or not they still remain.

(11) Wild boar

It mainly inhabits the lowland areas and damages to farm crops in the form of digging are reported. (12) Ibex

We confirmed its inhabitance by detecting the pawprints in the snow. Grazing by livestock such as goats and sheep expanded to an elevation as high as 3,400 m even in November when snow covers the ground. The habitat of the ibex is limited to steep slopes and bluffs beyond the reach of livestock, and this animal is said to migrate to the lower elevation areas when the snow becomes deep in midwinter.

Ibex is an authorized hunting target but not without permission. Illegal hunting by those who possess guns also takes place, and the population seems to have greatly decreased. The ibex is said to be extinct in the areas around Sary Tash.

\section{(13) Argali}

Its present habitat is restricted to areas near the national border in Bor-Dobo (Bordoba), across the Kyzyl-Art Pass, towards Tajikistan and also around Altyn Mazar. Those inhabiting Tajikistan are assumed to move across the national border towards China. Some appear in Kyrgyz in the summer season. Further, inhabitance around Nura, near the national border towards China, had been reported, but it is unclear whether or not they still exist there. The Alai Range and the $\mathrm{Za}$-Alai Range were a vast habitat for the Argali until around 1950, but high hunting pressure is said to have caused the decline in number.

(14) Others

Feeding on pasture grass by grasshoppers and feeding on potato by Colorado beetle occur as farming damages. Chronic lack of water is also becoming a profound social issue.

\section{Some information from local hunters}

This section provides an overview on the major issues related to conflicts between the large mammals and the local residents in the area, the information of which was provided by some local hunters as well as residents.

The first issue is with regard to the establishment and settlement of packs of 'rural' wolves near some of the villages in the valley. Through our interviews, we discovered that widespread damage by wolves to domestic animals is one of the largest social problems in the area since the area relies heavily on transhumance.

The interview survey shows that wolves had been systematically hunted as mammalian pest control in the former Soviet era. After the collapse of the Soviet Union, however, the central government of Kyrgyz did not offer support towards the control of the wolf population, such that the local residents had to start the control procedures by themselves. The Alai Valley area, which is the most remote area in the country, has been experiencing a decrease in population, especially the working population. Hence, aging of local hunters and shortage of succeeding hunters appear to pose serious problems.

The government and local authority now take no effective actions towards the control of the wolf 
population except in order to reward those who hunt wolves to mitigate the widespread damage caused by wolves; a reward of Som 2,500 (Som 41 = USD 1.00 in March 2009) per head is offered to a hunter. However, this is the only measure that is taken to help the villagers cope with the issue and effective measures such as exterminating the 'rural wolves', which has not been effectively practiced because of the lack of budget and the shortage of hunters, have not been adopted. However, it is essential that a systematic approach towards killing the 'rural wolves', be adopted.

As a result of this lack of initiative on the part of the government, large-size packs of rural wolves, composed of as many as 20 heads, have begun to settle near the villages. The presence of these packs is most likely to grow into a more serious social issue in the future because the poverty in the area is not one that can be easily solved in a short period. Moreover, hunting and killing the wolves in and around the villages may not be the only solution. Nevertheless, it is necessary to remove such wolves from residential areas in order to avoid any damage to the local residents.

The second issue that our interviews identified was the illegal hunting of ungulates, which is a significant menace to wildlife management. As stated previously, the basic industry in this area is characterized by transhumance. Pastures had expanded deep into the mountains a long time ago, and the lands that had been once been occupied by wildlife have been utilized for herding since ages. This implies that domestic animals have competed with ungulates such as ibex and argali for food resources since a long time. The hunting of mammalian pests such as wolves has been practiced in the pastures distributed in the high-altitude tributary valleys in order to protect the domestic animals especially in the past. At the same time, hunting of the ungulates is most likely to have been conducted in the same area. As a result, the habitat of the ungulates such as ibex and argali is now limited to the extremely steep slopes in the remotest tributary areas where it is not possible to rear domestic animals. Thus, it is rather difficult to observe the ibex and argali in the area today, unlike in the southern flank of the Za-Alai Range in Tajikistan.

After their extinction in areas all over the Alai valley, the argali are found only on the national border between Kyrgyz and Tajikistan near the Kyzyl Pass, where humans have no access. In fact, this species has now been given the 'Near Threatened ver3.1' conservation status of the International Union for Conservation of Nature and Natural Resources (IUCN, 2009). The argali currently inhabits the southern flank of the Za-Alai Range in Tajikistan (CDE, 2005; Watanabe and Kasirov, 2007; Watanabe, 2008), although trophy hunting in the Tajik National Park is a large conservational issue (Haslinger, 2004). The population of argali in the Tajik Pamirs seems to be quite large if it can be assumed so by easy eye-observation in the field. In contrast, it is clear that the argali population in the study area is moving from endangered to extinct.

The extinction area of the ibex is also expanding in the Alai Valley region today. This is because massive hunting with automatic firearms, usually possessed by the police/security department and the army, is practiced to kill the ibex; in fact, some local residents have witnessed trucks carrying a load-full of ibex carcasses especially in the southern flank of the Alai Range. A young resident reported that a hunter living in Daroot-Korgon normally kills 80-90 ibex per year. Here, the hunting of ibex for its meat is practiced even today; a local resident reported that ibex meat is sold at a price of Som 300 per kilogramme at the local market. It is important that such illegal massive hunting be stopped immediately and effectively, and the only way in which this can be accomplished is if some necessary measures are taken in the area. 


\section{Questionnaire survey}

The details of the results of the questionnaire survey will be presented elsewhere. This section describes only the results of the awareness of the local residents of the Pamir-Alai Transboundary Conservancy Area (PATCA) project (AGRECO Consortium, 2007; Baird, 2008) because it is related to wildlife conservation issues. The PATCA project is supported by the EU, which intends to conserve wildlife in the area through the creation of the PATCA. The PATCA will be enforced by connecting the existing Tajik National Park (extending from the southern flank of the Za-Alai Range) and a newly created conservation area on the Kyrgyz side (northern flank of the Za-Alai Range).

Table 2 shows the percentage of residents who are aware/unaware of the PATCA project. It was rather surprising to learn that only $16.9 \%$ of the respondents $(56 / 331)$ were aware the project. Forty-four persons among the 56 respondents who were aware of the PATCA project responded to the next question, 'Do you think the PATCA will bring nature conservation to this area?' and 84.1\% of the respondents expressed a positive view (Table 3-1). However, compared to these results, more respondents (93.4\%) expressed a positive view towards the economic benefits brought about by the PATCA project (Table 3-2).

Table 2. The awareness of the PATCA Project by the residents in the Alai Valley.

\begin{tabular}{cccc}
\hline \multirow{2}{*}{ Number of respondents } & Yes & No & Total \\
\cline { 2 - 4 } Percentage & 56 & 275 & 331 \\
& 16.9 & 83.1 & 100.0 \\
\hline
\end{tabular}

Data from the questionnaire survey in 2008.

Table 3. Expectations from the PATCA project by the respondents who are aware of the project.

\begin{tabular}{lcccccccc}
\hline & $\begin{array}{c}\text { Number of } \\
\text { respondents }\end{array}$ & $\begin{array}{c}\text { Strongly } \\
\text { yes }\end{array}$ & Yes & $\begin{array}{c}\text { Do not } \\
\text { know }\end{array}$ & No & $\begin{array}{c}\text { Strongly } \\
\text { no }\end{array}$ & Total \\
\hline $\begin{array}{l}\text { 1. Do you think } \\
\text { 'PATCA' will bring nature onservation }\end{array}$ & 44 & 15.9 & 68.2 & 13.6 & 2.3 & 0.0 & 100.0 \\
$\begin{array}{l}\text { to this area? } \\
\begin{array}{l}\text { 2. Do you think } \\
\text { 'PATCA'will bring economic benefit to } \\
\text { this area? }\end{array}\end{array}$ & 45 & 20.0 & 73.4 & 2.2 & 4.4 & 0.0 & 100.0 \\
\hline
\end{tabular}

Data from the questionnaire survey in 2008.

\section{Conclusions}

The collapse of the former Soviet Union led to a drastic transformation of the life of the local residents in the Alai Valley; previously, the government had controlled the people's life, but now individual abilities and skills would decide the quality and even the style of their lives. This transformation also led to changes in the relationship between the wildlife and local residents in the area. The establishment/settlement of the large-size packs of the 'rural wolves' near the villages is one such example. Massive meat-hunting of the ibex today and the argali before that, most probably due to the almost 'lawless' situation in the area today, unlike the strong control during the Soviet era, is another example.

Interestingly, these issues are quite different from the major issues observed in the Tajik side. The 
Alai Valley area needs strong and effective measures to conserve endangered species and eliminate the rural wolves from the residential areas. The PATCA project is expected to serve as one of the measures that can contribute to such issues, although it is important to publicize the project to the local residents.

\section{References}

AGRECO Consortium (2007): Support to the Establishment of the Pamir-Alai Transboundary Conservancy Area (PATCA) between Kyrgyzstan and Tajikistan Inception Report-April 2007. AGRECO Consortium.

Baird, D.R.(2008): Support to the Establishment of the Pamir-Alai Transboundary Conservancy Area (PATCA) between Kyrgyzstan and Tajikistan: Biodiversity Information Management System and Geographic Information System. Mission Report, 3.

CDE [Centre for Development and Environment] (2005): Synthesis Report. Baseline Survey on Sustainable Land Management in the Pamir-Alai Mountains. CDE, University of Bern and the United Nations University.

Editorial Board of the Chinese Academy of Sciences (ed.) (1979): Natural Geography and Animal Geography of China. Science Press, Beijing.

Haslinger, A. (2004): The Challenges for Nature Conservation in the Tajik National Park. Master's Thesis, University of Bern.

IUCN (2009): The IUCN Red List of Threatened Species. http://iucnredlist.org. <accessed in May 2009>

Kyrgyz Republic (2002): Mountain of Kyrgyzstan. Kyrgyz Republic, Bishkek.

Kyrgyz SSR Academy of Sciences (1987): Kyrgyz SSR Atlas. Kyrgyz SSR Academy of Sciences, Bishkek.

MacDonald, D.W.(ed) (1986): The Encyclopedia of Mammals. Heibonsha Ltd. Publishers, Tokyo.

Sekai Bunka Publishing (1985): Encyclopedia of Animal. Sekai Bunka Publishing Inc. Tokyo.

Watanabe, T. (2008): Current status and issues of ecotourism in the Pamirs. Chiri (Geography), 53 (1), 47-55. [in Japanese]

Watanabe, T. and Kasirov, K. (2007): Values and management of Tajik National Park in the Republic of Tajikistan. Kokuritsu Kouen (National Parks), No. 651, 26-28. [in Japanese]

Watanabe, T., Anarbaev, M., and Iwata, S. (2008): Protected area and tourism development in the Kyrgyz Republic. Geographical Studies, 83, 29-39. [in Japanese] 